\title{
The Role of Hydrologic Processes in Catchments
}

\author{
Ariwadun Martha Ekundayo \\ Department of Geography, Isaac Jasper Boro College of Education, Sagbama Bayelsa State, Nigeria
}

\begin{abstract}
Hydrological processes within a catchment perform an important role in the functioning of the ecosystem, by incorporating the complex processes (physical, chemical and biological) that sustain life. Water is a very vital factor that determines the efficiency of the ecosystem, species composition and biodiversity, hence the imperativeness of a review of the catchment hydrological processes causing runoff. Some of the models, such as the Stochastic and the Physical and Probability Distribution Models, will be reviewed. The factors affecting these hydrological processes, determining their functioning within the catchment will be reviewed to examine their effects on the productivity of the basin. For proper catchment management, this review is important for examining integration and understanding the important challenges of the interaction between economic, environmental, and productivity values of catchments as complex socioecological systems. Catchments have common hydrological characteristics but vary in their runoff response within the basin which is subject to the dominant hydrological factor controlling the catchment.
\end{abstract}

Keywords:- Catchment, models, hydrological processes and climate change.

\section{INTRODUCTION}

A catchment is an area of land that is drained by a river and its tributaries. The catchment at various scales within a defined area forms a landscape element that integrates all aspects of the hydrologic cycle, which can be studied, quantified, and acted upon (Wagener et al., 2004). The drainage basin in hydrology is referred to as a logical unit of focus suitable for studying the movement of water within the basin because precipitation is one of the main sources of water discharging from the basin outlet. the of the bulk of water that discharges from the basins. The experiment by two French citizens, Pierre Perrault and Edme Mariote, using a Paris basin showed that rainfall was more than enough to cause runoff in the River Seine about 400 years ago. This firmly established the fact that precipitation was the source of runoff within the basin (Manning, 1997).

Naturally catchments are typical examples of an open system with respect to the fluctuations in both input and output of water and other quantities (Dooge 2003), having some degree of organisation can be categorised as complex environmental systems (Dooge, 1986; Sivapalan, 2005). The utmost input is rain, nevertheless, snow, hail and dew all act as inputs too, especially in the polar and Antarctic regions. Temperature is equally an input. The final output is water flowing out of the basin, usually known as river discharge. Other processes within the basin include infiltration, groundwater recharge, evapotranspiration, evaporation, soil water storage and interception. They are divided into stores (interception and soil water, among others), transfers (evaporation and evapotranspiration) and flows (runoffs and base flow).

Catchment hydrology focuses on the interplay between the various hydrological processes, thereby causing runoff responses within the river basin. The study of catchment hydrology is very important to man because of its significance in determining the degree and likelihood of water pollution, flooding, drought, and availability of water in both rural and urban areas. This is because there are several factors controlling the basin as a system. These include climatic factors (rainfall, temperature, climate change), catchment characteristics (topography, soil, geology), and anthropogenic modifications (land use) amongst others which are responsible for the uniqueness and diverse nature of each basin, including water quantity and quality. The ability to successfully manage both land and water resources for the sustainability of the environment to enhance sustainable development depends to a large extent on the proper functioning of the hydrological processes with minimal human alterations.

\section{CONCEPTS, MODELS AND METHODOLOGICAL DEVELOPMENTS}

A Simplified conceptual representation of part of the hydrologic cycle is referred to as hydrological models (Ayoade, 1988). Primarily they are used for hydrological prediction to enhance the knowledge of hydrological processes. According to Pechlivanidis et al. (2011), hydrological models are of great significance for several applications such as, flood prediction and design, water resource planning, development and management, and coupled systems (water quality, hydro-ecology and climate) modelling, There are several limitations to accessibility of spatial-temporal data mainly due to resource constraints and the insufficient series of available measurement techniques required, therefore the extrapolation of data from measurements obtainable over time and space. Furthermore, it is imperative to assess the potential hydrological impact of future system response to land management and climate change amongst others

\section{A. Hydrological Models}

Hydrological modelling according to Islam, (2011) entails formulation of mathematical models to illustrate the interaction between the hydrologic processes as well as represent them (evapotranspiration, interception, infiltration, sub-surface flow, surface flow, precipitation, and snowmelt), 


\section{$>$ Physically-based Models}

Centred on the continuum mechanics, physically based models' characterize the constituents of hydrological processes such as overflow, evapotranspiration infiltration and saturated and unsaturated flow zones by means of governing equations of motion in other to designate the conduct of physical system in relations to motion as a function of time.

Normally, equations of motion of the basic processes are resolved mathematically using a finite difference or a finite element spatial discretisation in order to make the variables suitable for numerical evaluation to enhance implementation on digital computers; though, solutions analytical can exist (Wheater et al., 1993). Irrespective of calibration, in theory, physically-based models are defined by exclusively measureable parameter which runs continuous simulation of the runoff response (Beven, 2001). Models such as these are based on powerful compilation of the relevant idealised procedures, however raises a number of vital issues (physics behind the model structure largely based on laboratory or small-scale in-situ field experiments). This affects the nature of the experiments themselves thus raising applicability uncertainty (Beven, 2004). Computational burden and data requirements can be reduced by using simplified physics/mechanics to represent the physics (Green and Ampt, 1911; Mein and Larson, 1973), leading to deviance from the physical basis and further questionability.

An example of physically-based model is the water balance equation. The water balance equation for a given catchment can be written as:

$\mathrm{P}=\mathrm{ET}+\mathrm{Q}+\mathrm{D}+\Delta \mathrm{S}$

where $\mathrm{P}$ is the precipitation, ET is the actual evapotranspiration, $\mathrm{Q}$ is the stream flow, D is the recharge to the ground water, and $\Delta \mathrm{S}$ is the change in soil water storage.
The evapotranspiration and stream flow terms in equation (1) can be rewritten as:

$\mathrm{ET}=\mathrm{I}+\mathrm{T}+\mathrm{E}$

where $\mathrm{I}=$ interception loss, $\mathrm{T}=$ transpiration, and $\mathrm{E}=$ soil evaporation;

$\mathrm{Q}=\mathrm{OF}+\mathrm{BF}$

where $\mathrm{OF}=$ overland flow and $\mathrm{BF}=$ base flow

\section{Stochastic Model (Runoff Curve Number Method)}

One of the ways surface runoff can be estimated directly is from conceptual models, such as the runoff curve number (RCN) method (McCuen, 2003; Mishra and Singh, 2003). The RCN method is an empirical parameter in hydrology used for predicting infiltration or direct runoff from raiOnfall excess, developed by the USDA Natural Resources Conservation Service (USDA, 1986). Runoff from small sized catchments and hill slope plots were monitored and analysed by the USDA using the RCN, previously known as the Soil Conservation Service (SCS). This method is used generally and effective for determining the estimated volume of direct runoff from a rainfall event in a specific area. The area's hydrologic soil group, land use type, treatment and the hydrologic condition determines the RCN. The runoff curve equation 4 is written below:

$Q= \begin{cases}0 & \text { for } P \leq I_{a} \\ \frac{\left(P-I_{a}\right)^{2}}{P-I_{a}+S} & \text { for } P>I_{a}\end{cases}$

where:

$\mathrm{Q}=$ direct runoff depth $(\mathrm{mm}), \mathrm{P}=$ rainfall depth (mm), $S=$ potential maximum retention $(\mathrm{mm})$, and $\mathrm{I}_{\mathrm{a}}=$ initial abstraction (i.e. amounts of interception, infiltration, surface storage, and many others) before runoff takes place $(\mathrm{mm})$. It has generally been assumed that $I_{a}=0.2 \mathrm{~S}$ although more recent research has found that $I=0.05 \mathrm{~S}$ may be a more appropriate and accurate relationship. The curve number hydrograph is shown in Figure 1 below, capturing series of direct runoff plotted against rainfall series in inches: 


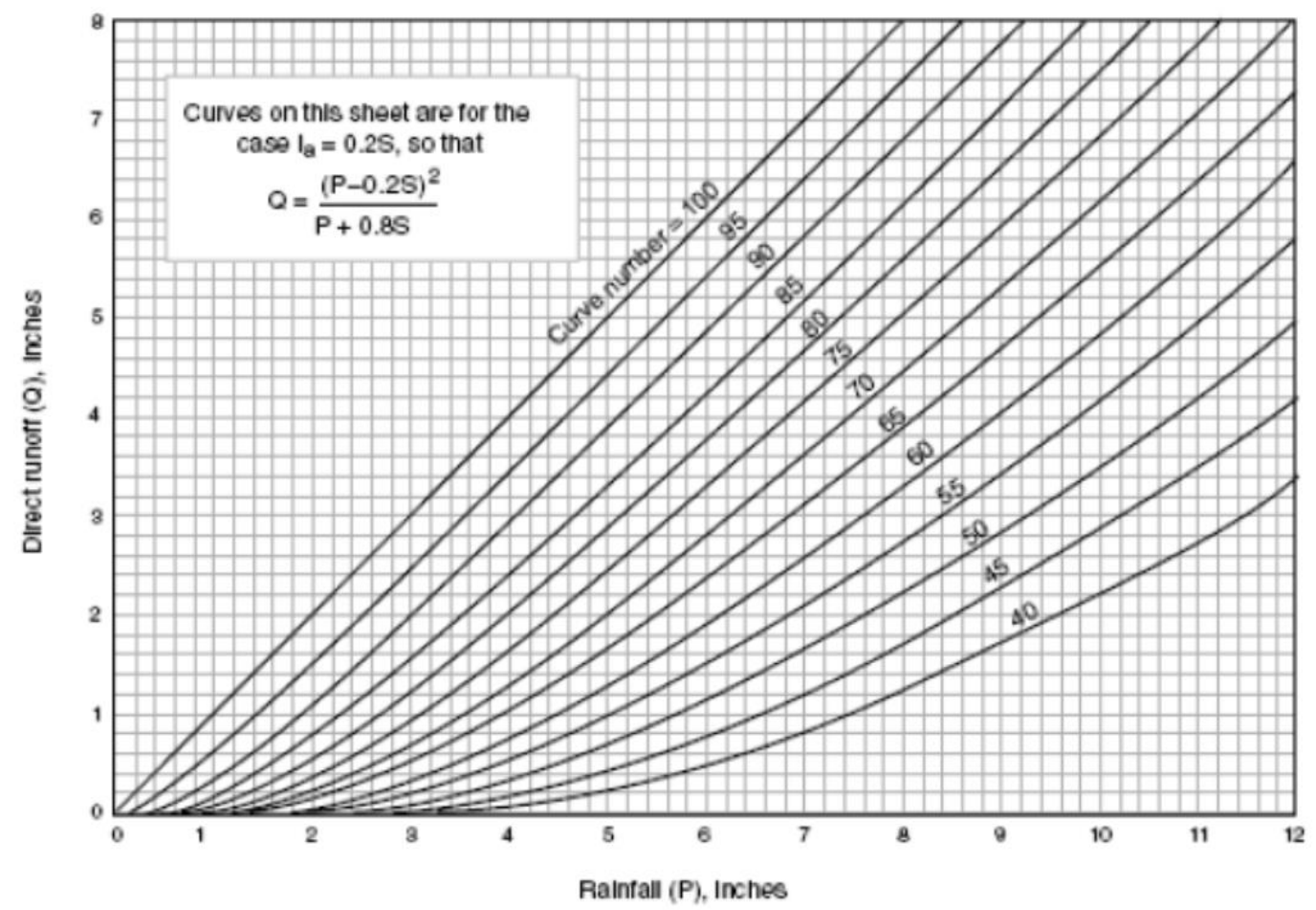

Fig 1:- Curve number hydrograph

Source: USDA, (1986)

The runoff curve number, $C N$, is then related as $\mathrm{S}=1000 / C N-10$

where $C N$ has a range of $30-100 . \mathrm{CN}$ varies amongst land covers. Lower numbers indicate low runoff potential, while larger numbers are for increasing runoff potential. The lower the curve number, the more permeable the soil is leading to a decline in direct runoff (Equation 5). Runoff only begins when initial abstraction has been achieved (Hawkins et al., 2002).

Saturated hydraulic conductivity (K-sat) can be estimated from a range of data obtained through the rainfall simulators as in the mass balance equation 6 :

$F=p-q$

6

where: $f=$ infiltration rate $(\mathrm{mm} / \mathrm{h}), p=$ rainfall intensity $(\mathrm{mm} / \mathrm{h})$, and $q=$ runoff rate $(\mathrm{mm} / \mathrm{h})$.

A single $\mathrm{CN}$ or Ksat value may not represent the watershed characteristics because of the expected variability in soil texture, average slope, moisture condition, as well as land use and cover. However, within the field scale, the variability in these factors may be small; thus, a single $\mathrm{CN}$ or Ksat value may represent the field (West et al., 2008).

Rainfall for most of these models is on a daily timestep. Poor results are often obtained because most storms are small, and the $\mathrm{CN}$ model does not work well for small events, certain times of the year.

\section{$>$ Probability Distribution Model (PDM)}

A general conceptual rainfall-runoff model known as the Probability Distribution Model (PDM), transforms rainfall and potential evaporation data to flow at the catchment outlet (Moore 1999; Moore et al., 2005). The illustration of the original form of the model (Figure 2), as runoff production at a point in the catchment, controlled by the soil absorption capacity, treated together with canopy and surface detention to take up water. This is hypothesised as a simple store with a given storage capacity. By considering the fact that different points in the catchment have differing storage capacities and that spatial variation can be described by a probability distribution, a simple runoff production model which integrates the point runoffs to yield the catchment surface runoff into surface storage is formulated. Groundwater recharge from the soil moisture store that passes into subsurface storage, together with any fixed flow representing, say, compensation releases from reservoirs or constant abstractions, forms the model output.

Suppose that runoff production at any point within ' $t$ ' a river basin may be conceptualized as a single storage or tank of capacity (c'), representing the absorption capacity of the column at that point. The storage takes up water by rainfall $(p)$ and loses water by evaporation $(E)$, until the storage fills and spills, generating direct runoffs $(q)$. The equation is shown below:

$q^{\prime}= \begin{cases}P-E-\left(c^{\prime}-S_{0}\right) & P>c^{\prime}+E \\ 0 & P \leq c^{\prime}+E\end{cases}$ 
From the equation above, $S_{o}$ is the initial depth of water in storage; and $\mathrm{P}, \mathrm{E}$, and q' represent the depth of rainfall, evaporation and the resulting direct runoff over the interval being considered.

The storage capacity at any point $\mathrm{c}$, is considered as a random variate with probability density function $\mathrm{f}(\mathrm{c})$, and so the proportion of the river basin with depths in the range $(c, c+d c)$ will be $f(c) d c$. The proportion of the basin generating runoff, capturing the contributing area at a time for a basin of area $\mathrm{A}$, is

$$
A c(t)=F\left(C^{*}(t)\right) A
$$

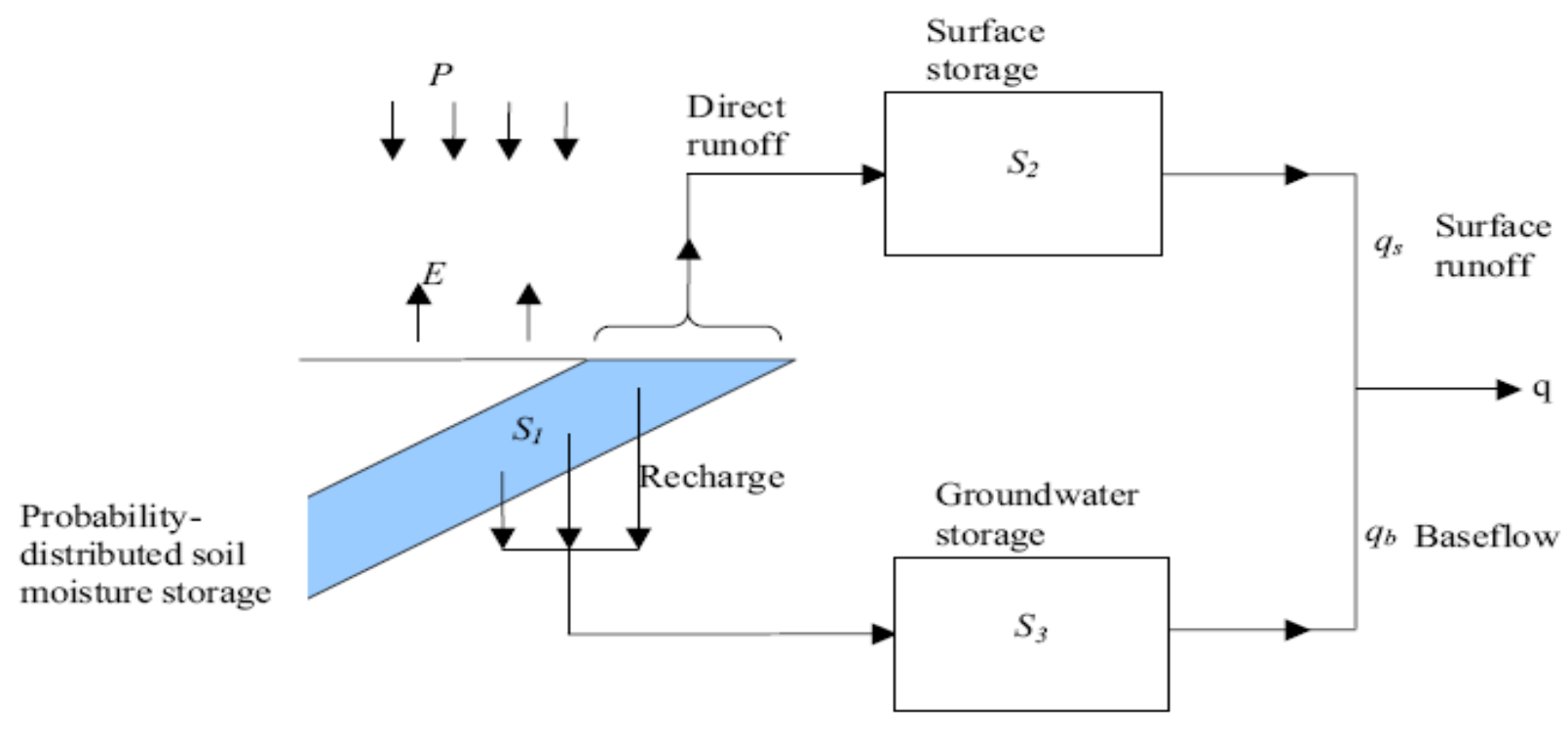

Fig 2:- The PDM rainfall run-off model

Source: Moore et al. (2005)

The instant direct runoff rates per unit area from the basin is the product of the net rainfall rate, $\pi(t)$, and the proportion of basin generating runoff, $\mathrm{F}\left(\mathrm{C}^{*}\right)$; that is $\mathrm{q}(\mathrm{t})=\pi(\mathrm{t}) \mathrm{F}\left(\mathrm{C}^{*}(\mathrm{t})\right)$.

When an error occurs between the model prediction $\mathrm{q}$ and the observed value of basin runoff $\mathrm{Q}$, the error might be due to misspecification of state variable $\left(s_{1}, S_{2}, S_{3}, q\right.$ and Q) or errors in rainfall measurement. A formal approach to state correction is provided by the use of Kalman filter algorithm (Moore and Weiss, 1980a). The general applicability and popularity of error-prediction as an updated tool commends the PDM use as an off-the-shelf technique. State correction is usually the preferred choice with the PDM model (Moore, 2005).

\section{RESEARCH IN CATCHMENT HYDROLOGY}

In the mid-20th century, according to researchers (Singa et al, 2016; UNWWDR, 2015; Richy et al, 2015), the capability of water supplies to meet the increasing demand of industries and the dynamic nature of the population was a great concern in the developing countries. This is one of the reasons why further research in major catchment areas of water supplies is required. Researchers have engaged in several studies pertaining to river basins studies, all over the world, in order to proffer solutions to this problem of inadequate water availability, flooding, drought, and many others. The review of some of the literature relevant to this study will be done below.

\section{$>$ Drainage Basin as a System}

How a catchment reacts to precipitation is yet to be wholly understood, despite the great advancement in the science of hydrology (Beven, 2001). This could be accounted for by the extremely non-linear nature of hydrological systems and vital features of the catchment, (hydraulic conductivity of the soil and basins climatic conditions), remain highly heterogeneous in space. The drainage basin as an open system shows the basin as made up of parts working together as a whole.

Faniran et al. (2006) claim that (Horton 1945) view the drainage basin to be the most useful and profitable geomorphic unit because it's an open physical system consisting of quantifiable outputs (evaporation and evapotranspiration) and inputs (precipitation) of energy and matter. Drainage basin is said to be more than just a geomorphological unit; it is also a hydraulic and hydrological unit having water resource as a unifying factor, since river basins are a source area of precipitation being disposed of in several processes taking place within the hydrological cycle (Ayoade, 1988). The drainage basin referred to as an open system receives inputs, such as energy from the sun for evaporation, precipitation (rain, snow). This is liable for output such as stream runoff into the sea, evaporation of water into the atmosphere and transpiration from plants. (Chorley, 1969; Ayoade, 1988; Dingman, 1994; Faniran et al.,2006). As an open system, water are stored on surfaces in the form of rivers, ponds, lakes, depressions, glaciers, vegetation stores of water, soil water and groundwater. 


\section{> Hydrological Processes within the Basin}

Hydrological processes take place within the drainage system as a whole. Understanding these processes enhances the understanding of how the drainage as a system works. Some of these processes are precipitation, evapotranspiration, infiltration, interception, through flow, groundwater store and flow, surface flow or runoff and channel flow. Hydrology involves a step-by-step study of the water cycle, and the understanding of the interplay of these functions is important to succeed as a hydrologist (Manning, 1997). Some of these processes are reviewed below.

\section{- Precipitation}

The evaporation-condensation process, over time, brings about precipitation, which falls as rain, hail, sleet or snow. Rainfall variability in space and time is high; hence, it is a non-linear phenomenon. Precipitation distribution varies both spatially and temporally within and between catchment basins, making measuring difficult, especially within basins. Globally, tropical basins are likely to experience moderately steady patterns of precipitation and runoff all through the year. On the contrary, some other parts of the world have more unpredictable or seasonal climates with desert basins laced with dry drainages that get filled only after occasional deluges.

In the conterminous USA basin, Precipitation increases over land have been associated with consistent river runoff increase (Groisman et al., 2001) whereas the response of a river basin to a rainfall event greatly depends on the nature and conditions of underlying soils (Xizhi Lv et al. (2019); Shrestha et al., 2008). Rainfall distributions in catchments are controlled by interception, infiltration, evaporation, and evapotranspiration within the watershed. According to (Ayoade, 1975), soil moisture, groundwater storage and runoffs into streams and rivers are attained as rainfall replenishes them; while a significant amount of rain is lost through the evapotranspiration processes. As noted by Ayoade (1988), determining the amount of precipitation that falls in a given area within the catchment is of great interest to hydrology because it introduces the input into the hydrological system within a given area. Onafeso (2012), in his research on the lower Niger using a trend analysis, claims that rainfall and runoff are decreasing northward but there is an increase in rainfall and runoff pattern southward over the years. Rainfall, to a large extent, determines runoff within a catchment.

\section{- Interception}

Once the rain drops on the earth surface it enters the grip of earth's gravity, depending mainly on the topography. Manning (1997) argues that, in the initial phase of the storm, the rainfall is interrupted by trees and vegetation through the process known as interception were water flow down the vegetation as stem flow, taken up and lost as transpiration or can be dripped off leaves. Interception is viewed as the portion of the rainfall captured by surface storage, before running off into streams, infiltrate into soils or evaporate during the event and shortly after the rainfall has ceased (Ayoade, 1988; Gerrits, 2010).
In the view of National Water Commission [NWC] (2007b), interception occurs when surface water flows or groundwater are disrupted, reduced or redirected, apart from precipitation. Its main emphasis is, on the fluxes during recharge and runoff, rather than diret changes to precipitation. Duggan et al. (2008), further suggest interception events as human-induced activities that intercept significant volumes of water and thus leading to a decline in the amount of water flowing into ground and surface waterbodies. The amount of water that finally flows into the various water bodies depends further on the amount, duration and intensity of rainfall.

Interception unevenly redistributes the rainfall of a location due to funnelling of the vegetation (Germer et al.,2006; Gerrits et al.,2009a). Three main components of interception are identified, namely interception loss, throughfall and stem flow. Interception loss is the part of the precipitation remaining on leaf and plant surfaces, which is later evaporated into the atmosphere or absorbed by the surfaces. The one on the plant surfaces is said to have little effect on water balance of a drainage basin because the energy used to vaporise water cannot be used for evapotranspiration. The part of the intercepted water that reaches the ground through vegetative surfaces is known as throughfall (Ayoade, 1988). Interceptions are storage systems within basins.

\section{- Factors Affecting Interception}

Ayoade (1988), further mention two major factors affecting interception, namely vegetation canopy and precipitation. For the latter, the following characteristics are important: the amount, duration, intensity, frequency of rainstorm and length of time and evaporative conditions between rainstorms. For vegetation, the density of the vegetation, morphology of the vegetation, species composition, and age of vegetation are main factors. Daura (1995) asserts that keeping agricultural lands bare is potentially dangerous, as it can yield runoff and erosion losses many times greater than lands under natural fallow or intercropping. According to Brown (2005), the lengthiest and most detailed record of paired catchment afforestation research, with emphasis on permanent vegetation modification from grassland to forest were identified in South Africa. Series of generalised curves to predict the effect of afforestation on annual total flows and flows as a function of plantation, species planted, age and site suitability were developed using data from South African afforestation experiments (Scott and Smith 1997). They resolved in their findings that, forest cover reduction and increase are the bases for increase and decrease in water yield respectively, resulting to changes in surface runoff or base flow.

\section{- Evaporation and Evapotranspiration}

Solar radiation is the major energy which drives the hydrological cycle. The main natural storage reservoir for water are the sea or ocean which is the starting point of a drop of water moving, through the water cycle into the atmosphere and returns back to the sea during rainfall as surface or base flow. The movement of water droplets from 
the ocean surface through evaporation into the atmosphere upward are in form of invisible water vapour, driven by solar energy from the sun. The vapour rises to a cooler region of the atmosphere where it can no longer retain its load of invisible water vapour and so gives up its latent heat of vaporisation, and reverts to a liquid state known as condensation. The combined losses of water through transpiration and evaporation are known as evapotranspiration

Manning (1997) views evapotranspiration, as referring to three major processes that return moisture to the atmosphere over the vegetated land areas of the earth. These are evaporation of precipitation intercepted by plant surfaces, evaporation of moisture from plants through transpiration, and evaporation of moisture from soil surface.

The factors affecting evaporation and evapotranspiration have been summarized by Ayoade (1988) and Nagle (2000) as climatic and non-climatic factors. The climatic factors include vapour pressure, air temperature, precipitation and wind. The non-climatic factors include rock or soil surface, human activities and vegetation cover. As pointed out by Ayoade (1975), in the northern part of Nigeria potential evaporation is on the increase than in the south, owing to the predominant climatic conditions of high insolation, low humidity, clear skies and relatively strong winds factors, intensifying evaporation rates. With increasing distance towards the northern part of Nigeria, specifically the north-eastern part of Nigeria, the amount of water surplus diminishes over space and time; hence runoff is of little significance. In view of this and based on the short duration of the rainy (45 months) season, the soil might not attain field capacity. High rates of evaporation are common in arid environments than in humid tropical regions because of dense vegetation covering the land surface (Manning, 1997). Researchers have also discovered that, globally, evapotranspiration involves the movement of a substantial amount of water within the water cycle, giving it an important role in the hydrological cycle. Ellensburg et al, (2018) studied the relationship between evapotranspiration and streamflow in the South-eastern United States at various time and space scales using Entropic analyses of observed (streamflow), observational-based (precipitation) and modelled evapotranspiration (ET) data. It was discovered that the uncertainty (or entropy) in streamflow and precipitation displayed significant spatial variability over the study area and less significance at greater temporal scales.

In contrary the knowledge of ET when a lessparameterized application of the Penman-Monteith equation was used to evaluate latent energy in relation to stream discharge, there was a greater reduction in proportion of uncertainty in smaller basin, hence, contributing significant information to streamflow modelling at the daily time period. Conversely, at longer time periods, precipitation effect becomes predominant. This result is not same for all climate and even within same basin the

\section{- Infiltration}

Horton (1933) used Ward's infiltration to explain the process by which the absorption of water by the soil occurs over time. Some of the water that falls as rain, if not intercepted by vegetation or the roof, penetrates through the topsoil layer into the rock beneath, if the soil and rock are permeable. This process is called infiltration, This water will then move through the soil as soil flow or through the rock as through flow, and over the land as overland flow or surface runoff into streams and rivers when the soil pore spaces are full to capacity. Infiltration is one of the major sources of water distribution to groundwater.

The factors affecting infiltration are summarized by Ayoade (1988) as soil permeability, rainfall intensity, water quality, vegetation cover and human activities, among others. He further explains that, in urban areas, human activities are poignantly demonstrated, with permeable natural surfaces being replaced by impermeable man-made surfaces, thereby reducing infiltration rates and concomitant increase in overland flows. Ultimately, this increases risk of flooding in many urban catchments. Infiltration rate decreases with time over surfaces with persistent precipitation but, when infiltration rate reaches a steady state condition (that is rates do not change with respect to time), this is defined as the saturated hydraulic conductivity, or Ksat (Gupta et al., 1996; Papanicolaou et al., 2009)

\section{- Runoff}

The catchment is the most significant factor determining the river regime. The total volume of discharge and its distribution over time are two major characteristics of the runoff leaving a catchment. The discharge and distribution are usually shown in the hydrograph of a river or stream. The runoff as a phase in the water cycle is the story of water flowing across the streams and rivers. The constancy of flow has made rivers important to people. This entire process is between precipitation and stream flow. To fully understand the runoff process entails looking at the arrival of rain drops on the land and final delivery of water into the streams that carry it to the sea, called the runoff cycle (Manning, 1997).

The runoff cycle in arid regions differs from that of humid regions. In the former, groundwater is usually deep in the ground, well below the stream beds, and much of the stream flow depends on precipitation alone since long dry spells often separate storms. Therefore, most streams are often ephemeral or at best intermittent. In the humid environment, the streams are usually perennial in nature. Within the same basin, volume of discharge might also vary. Some factors have been discovered to be the reasons for this variation within the basin (Nagle, 2000). Stream channels are not static features on the landscape. They adjust to changing watershed conditions and evolve through time. An initial disturbance, or perturbation, significant enough to precipitate a channel response is often followed by a series of channel adjustments that bring the stream channel back into equilibrium. If the perturbation creates a permanent change to watershed conditions, such as in an 
urbanized setting, the channel will establish an equilibrium condition different from what existed prior to the disturbance. Some of the factors responsible for variation in runoff within and between catchment are discussed below.

\section{- Factors Controlling Runoff Characteristics}

$\checkmark$ Climatic factors

$\checkmark$ Anthropogenic or land use or human activities around the basin

$\checkmark$ Catchment characteristics (topography, geology, vegetation and soil type, stream density).

\section{$>$ Climatic factors}

Climate is one of the major factors affecting runoff in a basin. Some of the precipitation characteristics influencing runoff in a basin include intensity, duration area distribution of rainfall, form of precipitation, interception, evapotranspiration, soil moisture condition and antecedent rainfall conditions amongst others. Series of storm in rapid succession results in runoff and flooding conditions but the reverse is the case when a storm follows a period of dry weather, as is the case in arid regions. This follows certain sequence of events that may produce runoff, depending on the physical characteristics of the basin (Field and Lichvar, 2007). When soils are saturated and the storages reach their capacity in stream banks, further precipitation will cause immediate stream rise in levels. Hence, antecedent precipitation, which is an index of the water stored within drainage basin at the beginning of a new storm, is an important factor for predicting flood. In other words, peak flows do not occur immediately precipitation begins until the soil has fully reached its capacity.

In the cold regions of the world where precipitation is in the form of snow, temperature is an important factor determining the runoff pattern within the drainage basin. In spring, much of the snow pack begins to thaw and snowmelt tends to run off by overland flow towards streams, causing stream levels to begin to rise as soon as the ice begins to thaw due to the impervious surface caused by the ice pack. In addition, part of the increase in runoff from river basins containing 'permanent' ice and snow is likely attributable to melting of glaciers and permafrost rather than increased precipitation (Kulkarni et al., 2003; McClelland et al., 2004; Yang et al., 2004; ).

\section{$>$ Climate Change}

Xizhi Lv et al. (2019), using the Budyko theory, analyzed and summarized the effects of climate and watershed characteristic changes on stream flow in the Yellow River in China watershed. The summary states that annual stream flow decreased significantly and annual runoff amount declined by $26.87 \mathrm{~mm}(66.33 \%)$ during the change (1978-2010) period compared to the referenced (1951-1977) period. The sensitivity coefficients of runoff to precipitation, potential evapotranspiration and the watershed characteristic coefficients were $0.1809,-0.0551$, -27.0882 , respectively. This presupposes that an increase in rainfall or evaporation will lead to an increase or decrease in runoff, respectively.
Generally, climate change (6.5\%) and underlying surface conditions $(92.27 \%)$ are dominant contributors to stream flow change compared to other factors. The underlying surface of each catchment differs from catchment to catchment and even so varies from location to location on each catchment. The impact of climate change on catchment is gradual over the years compared to the nature of the rock material underlying the surface of the earth. In arid regions, the reverse is the case, as climate is a major determinant of runoff into streams. Ecosystems there are delicate, and under threat from groundwater withdrawals, climate change uncertainty and the management of surface flow.

\section{$>$ Anthropogenic or land use causes}

Human induced activities such as alteration of catchments during river diversion, extractions, dredging, vegetation changes and urbanization due to the dynamic human population leading to change in Land use is a vital factor in the runoff process affecting infiltration, erosion and evapotranspiration amongst other hydrological processes (Bosch and Hewlett, 1982, Hudson and Gilman, 1993, Brown et al., 2005, Croke et al., 2004, and Mango et al., 2011). These are said to dry season flows and increase peak flows, leading to greater water scarcity at critical times of the year and exacerbating erosion on hill slopes. The paired catchment studies have been widely used as a means of determining the magnitude of water yield change resulting from changes in vegetation cover (Stednick, 1995; Brown et al., 2005).

A comparative research was carried out by (Qazi et al, 2017), to examine the effects of forest degradation and soil disturbance on streamflow regime in Arnigad and Bansigad catchments located at Garhwal northern Himalayas of India, a highly seasonal environment with annual rainfall delivered within the four months of monsoon season (June -September) period. The two were similar (in size, underlying formation, rainfall pattern) catchments called Arnigad (covered with montane oak forest) and Bansigad (suffered advance to severe forest degradation before stabilizing) were monitored for runoff and rainfall. A physically-based recursive filter technique was used to separate Storm flows from base flow instead of an arbitrary straight-line and thus summary of the analysis followed thus; at the forested Arnigad, subsurface flow was dominant throughout the year with stream flow all through the year than Bansigad were infiltration-excess overland flow seems to be the dominant storm-flow and therefore streamflow was ephemeral in nature. The differences in river regime observation was centered on the importance of vegetation on hydrological cycles and the effects of deforestation or anthropogenic factor leading to decline in groundwater recharge 0ver time. Qazi et al, emphasized on the necessity for process -oriented studies to complement the recent research in infiltration-excess overland flow amounts, forest optimal hydrological functioning and observations of surface and subsoil hydraulic conductivities amongst others. 
Land use and management is an important factor affecting different processes in the watershed, such as surface runoff, erosion, recharge and evapotranspiration. As noted by Merz et al. (2010), land management practices in sectors such as forestry, agriculture and native vegetation management affect the current use of water resources. Modifications to these land management practices have the potential to cause impacts on water balance, and reduce runoff and groundwater recharge.

\section{CONCLUSION}

The hydrological processes discussed above are all interrelated and have great impact on water availability within a catchment. They also determine the amount of water that will sustain both plants and animals. Oyedele (2010) claims that, despite the fact that $70 \%$ of the earth is made up of water, a lot of people still find it increasingly difficult to get adequate water for consumption, cooking, washing, agriculture and manufacturing. The runoff responses of catchment basins are important for water management, be it for agriculture, industrial, or human use, and flood or drought prediction. Monitoring the factors affecting runoff will be of great importance to effectively managing water resources, as well as making policies and laws that will affect both human and the environment. Effective water management is necessary, and this requires appropriate decision support systems, including modelling tools.

\section{REFERENCES}

[1]. Ayoade, J. O. 1975. Water Resources and their development in Nigeria. International Association for Hydrological Sciences, Vol.20, No.4, 581-591.

[2]. Ayoade, J. O. 1988. Tropical hydrology and water resources. London: Macmillan.

[3]. Beven K. 2000a. On the uniqueness of place and process representations in hydrological modelling. Hydrology and Earth System Science 4 (2), 203-212.

[4]. Beven K. 2004. Robert E. Horton's perceptual model of infiltration processes, Hydrological Processes, 18, 3447-3460.

[5]. Bosch, J. M., Hewlett, J. D. 1982. A review of catchment experiments to determine the effect of vegetation changes on water yield and evapotranspiration. J. Hydrol. 55, 3-23.

[6]. Brown, E. A., Zhang L., McMahon A. T., Western W. A. and Vertessy A. R. 2005. A review of Paired catchment studies for determining changes in water yield from alterations in vegetation. Journal of Hydrology, 310:28 - 61.

[7]. Bradshaw, Michael and Weaver, Ruth. 1993. Physical Geography. London, Boston, and Chicago: Mosby

[8]. Chorley, R. J. 1969. The drainage basin as the fundamental geomorphic unit. In R. J. Chorley (Ed.), Water, earth, and man: a synthesis of hydrology, geomorphology and socio-economic geography (pp. 77 -99).London: Methuen.
[9]. Croke, B. F. W., Merritt W. S. and Jakeman A. J. 2004. A dynamic model for predicting hydrologic response to land cover changes in gauged and ungauged catchments. Journal of Hydrology, 291:115 -131 .

[10]. Dingman, S.L. 1994. Physical hydrology. Prentice Hall, Englewood Cliffs, 575pp

[11]. Dooge, J. C. I. 1986. Looking for hydrologic laws. Water Resources Research 22 (9), 46S-58S.

[12]. Duara, M.M 1995. Comparative analysis of runoff, soil and nutrient loss under different cropping systems. A Ph.D thesis, University of Ibadan.

[13]. Duggan K, Beavis S, Connell D, Hussey K and MacDonald B 2008, Approaches to, and challenges of managing interception, Waterlines Occasional Paper No. 5, February 2008, National Water Commission.

[14]. Ellenburg W. L, Cruise,J.F. and Singh V.P. 2018, The Role of Evapotranspiration in Stream Flow Modeling-An Analysis using Entropy. Journal of $\begin{array}{llll}\text { Hydrology } & 567 & \text { (2018), 290-304. }\end{array}$ www.elsevier.com/locate/jhydrol retrieved 7/14/2020

[15]. Faniran, A. and Jeje, L. K. 2002. Humid Tropical Geomorphology: A study of the geomorphological processes and landforms in warm humid climate, Heinemann Eduational books Nig,

[16]. Faniran, A., Jeje, L. K. and Ebisemiju, F. S. 2006. Essentials of geomorphology: Earth in the service of humans. Pent house Publication Nig.

[17]. Field J. J. and Lichvar R. W. 2007. Review and synopsis of natural and human controls on fluvial channel processes in the Arid West. US Army Corps.

[18]. Gerrits, A. M. 2010. The role of interception in the hydrological cycle. VSSD, Delft, the Netherlands.

[19]. Gerrits, A. M. J., Savenije, H. H. G., Pfister, L., 2009. Canopy and forest floor interception and transpiration measurements in a mountainous beech forest in Luxembourg. IAHS Redbook 326, 18-24.

[20]. S. Germer, H. Elsenbeer, J. M. 2006, Moraes. Throughfall and temporal trends of rainfall redistribution in an open tropical rainforest, southwestern Amazonia (Rondônia, Brazil). Hydrology and EarthSystem Sciences Discussions, European Geosciences Union, 2006, 10 (3), pp.383-393. ffhal$00304865 f$

[21]. Green W.H. and Ampt G., 1911. Studies on soil physics, 1: The flow of air and water through soils, $J$. Agric. Sci., 4(1), 1-24.

[22]. Groisman, P.Y., Knight, P.W., Karl, T.R., 2001. Heavy precipitation and high streamflow in the United States: Trends in the 20th Century. Bull. Am. Meteorol. Soc. 82, 219-246.

[23]. Gupta N., Rudra R.P. and Parkin G. (1996). Analysis of spatial variability of hydraulic conductivity at field scale. Canadian Biosystems Engineering, 48(1), 5562.

[24]. Hawkins, R.H. 1992. Asymptotic Determination of Runoff Curve Numbers. Journal of Irrigation and Drainage Engineering, Amer. Soc. Civ Eng., 119(2), 334-345. 
[25]. Hudson, J.A., Gilman, K., 1993. Long term variability in the water balance of the Plynlimon catchments. Journal of Hydrology 143 (3-4), 355-380.

[26]. Islam Zahidul, (2011), A Review on Physically Based Hydrologic Modeling Technical Report, DOI: 10.13140/2.1.4544.5924.

[27]. Report number: Unpublished Report, Affiliation: University of Alberta

[28]. Knighton D. 1984. Fluvial forms and processes. London Edward Arnold. 218 pp.

[29]. Kulkarni, A.V., Rathore, B.P., Alex, S., 2003. Is global warming changing snow ablation pattern and reducing glacial extent of Baspa Basin in the Himalaya? Intl. Arch. Photogramm. Remote Sensing Spatial Infor. Sci. 34, 1265-1269.

[30]. Manning, John C 1997. Applied principles of hydrology, 3rd edition. Published Upper Saddle River, N.J. Prentice Hall Earth Sciences Series.

[31]. McClelland, J. W., Holmes, R. M., Peterson, B. J., Stieglitz, M., 2004. Increasing river discharge in the Eurasian Arctic: Consideration of dams, permafrost thaw, and fires as potential agents of change. $J$. Geophys. Res. 109, D18102.

[32]. Merz S. K., CSRO and Bureau of Rural Science (2010); Surface and/or groundwater interception activities. Waterlines Report Series No 30. National Water Commission, Canberra

[33]. Mishra S.K. and Singh V.P. (2003). Soil conservation service curve number (SCS-CN) methodology. Kluwer Academic, Dordrecht, The Netherlands.

[34]. Mango L. M , Melesse, A. M. McClain M. E, Gann D., and Setegn S. G., 2011. Land use and climate change impacts on the hydrology of the upper Mara River Basin, Kenya: results of a modelling study to support better resource management. Hydrology and Earth System Sciences 15, 2245-2258.

[35]. Moore, R.J, 1999. Real time flood forecasting systems: Perspective and prospects. In: Floods and Landslides: Integrated risk assessment, R. Casale and C. Margottini (Eds). Springer, Berlin, Germany.

[36]. Moore, R.J., 2007. The PDM rainfall-runoff model. Hydrology and Earth System Sciences, 11(1): 483499.

[37]. Nagle G., 2000. Advanced Geography. Oxford: Oxford University press.

[38]. NWC [National Water Commission] 2007b, A Baseline Assessment of Water Resources for the National Water Initiative Level 2 Assessment, Water Availability Theme National Perspective, National Water Commission, Canberra.

[39]. Onafeso O. D. 2012; Analysis of changes in rainfall patterns and runoff predictions for the lower river Niger, Nigeria. An unpublished $\mathrm{PhD}$ thesis submitted to the Department of Geography, University of Ibadan.

[40]. Oyedele B. B. 2010. The geographical distribution of water supply in Ekiti State. An International MultiDisciplinary Journal Vol. 4 (2),71-79.

[41]. Papanicolaou A. N., Elhakeem M., Wilson C., Burras C. L. and Oneal B. 2008. Observations of soils at the hillslope scale in the Clear Creek Watershed in Iowa,
USA. Soil Survey Horizons, Winter 2008 edition, 8386

[42]. Pechlivanidis I. G., Jackson B. M. and Wheater H. S. 2011. Catchment scale hydrological modelling: A review of model types, calibration approaches and uncertainty analysis methods in the context of recent development in the technology and application. Global NEST Journal, Vol 13, No 3, 193-214.

[43]. Pidwirny, M., and Hussein, G. 2007. Drainage basin. Retrieved from http://www.eoearth.org/view/article/151794

[44]. Qazi N. Q., L. Bruijnzeel,A.S., P \& Ghimire C P. '(2017), Impact of forest degradation on streamflow Regime and Runoff Response to Rainfall in the Garhwal Himalaya, Northwest India. Hydrological Sciences Journal ISSN:0262-6667 (2150-3435 Online) https://www.tandfonline.com/loi/thsj20

[45]. Richey, A. S., B. F. Thomas, M.-H. Lo, J. T. Reager, J. S. Famiglietti, K. Voss, S. Swenson, and M. Rodell (2015), Quantifying renewable groundwater stress with GRACE, Water Resource. Res., 51, 5217-5238, doi:10.1002/2015WR017349.

ibs.onlinelibrary.wiley.com (retrieved

19 th November, 2019)

[46]. Scott, D.F., Smith, R.E., 1997. Preliminary empirical models to predict reductions in total and low flows resulting from afforestation. Water S.A. 23 (2), 135140.

[47]. Shrestha, M. S., Artan, G. A., Bajracharya, S. R., and Sharma, R. R. 2008. Using satellite-based rainfall estimates for streamflow modeling: Bagmati Basin, $J$. Flood Risk Management, vol. 1(2) pp.89-99. https://doi.org/10.1111/j.1753-318X.2008.00011.x

[48]. Sivapalan, M. 2005. Pattern, processes and function: elements of a unified theory of hydrology at the catchment scale. In: Anderson, M. (ed.) Encyclopedia of hydrological sciences. London: John Wiley, pp. 193-219.

[49]. Singa D.D., Tumbo S.D., Fatae M.H, Filbert R., and Maxi L. (2016) Effects of catchment characteristics and climatic conditions on reservoir water capacity in a drought prone area. African Journal of Agricultural Research Vol. 11(6), pp. 472-479, 11 February, 2016 DOI: 10.5897/AJAR2015.10304 Article Number: 95D585757122 ISSN 1991-637X

[50]. Singh V. P. 1995. Computer models of watershed hydrology, Water Resources Publications, LLC, USA.

[51]. Stednick, D. J. 1995. Monitoring the effects of timber harvest on annual water yield. Journal of Hydrology, 176, 79 - 95.

[52]. United Nations World Water Development Report (UNWWDR) 2015. Water for a Sustainable World. Published by United Nations Educational, Scientific and Cultural Organization, 7, place de Fontenoy, 75352 Paris 07 SP, France

[53]. Wagener T., Wheater H. S. and Gupta H. V., 2004, Rainfall-runoff modelling in gauged and ungauged catchments. London, UK: Imperial College Press, 1306 pp. 
[54]. Wheater, HS., Jakeman, AJ. and Beven, KJ. 1993. Progress and directions in rainfall-runoff modelling. In:Modelling Change in environmental systems. Eds. Jakeman , AJ., Beck, MB. and McAleer, MJ. John Wiley, Chichester, Chapter 5. 101-132

[55]. West L. T., Abreu M. A. and Bishop J. P. 2008. Saturated hydraulic conductivity of soils in the Southern Piedmont of Georgia, USA: Field evaluation and relation to horizon and landscape properties. Catena, 73 , 174-179.

[56]. Xizhi L., Zhongguo Z., Yongxin N., Juan S. and Henian W.(2019) The effects of Climate and catchment characteristic change on streamflow in a typical tributary of the Yellow River. Scientific Report. Nature Research, http://www.nature.com/scientificreports

[57]. Yang, D., Ye, B. and Shiklomanov, A., 2004: Discharge characteristics and changes over the $\mathrm{Ob}$ River watershed in Siberia. Hydrometeorology 5, 595610. 